\title{
SEDENTARY LIFESTYLE IN ADOLESCENTS IS ASSOCIATED WITH IMPAIRMENT IN AUTONOMIC CARDIOVASCULAR MODULATION
}

\author{
SEDENTARISMO EM ADOLESCENTESÉASSOCIADO AO COMPROMETIMENTO DA MODULAÇÃO \\ CARDIOVASCULARAUTONÔMICA \\ SEDENTARISMO EN ADOLESCENTESES ASOCIADO AL COMPROMISO DE LAMODULACIÓN \\ CARDIOVASCULARAUTONÓMICA
}

\author{
Romilson Domingues Nascimento \\ (Physical Education Professional) \\ Ariane Viana ${ }^{2}$ \\ (Physiotherapist) \\ Michelle Sartori' \\ (Physical Education Professional) \\ José Robertto Zaffalon Júnior ${ }^{3}$ \\ (Physical Education Professional) \\ Danielle da Silva Dias $^{2}$ \\ (Physical Education Professional) \\ Janaína de Oliveira Brito Monzani4 \\ (Physical Education Professional) \\ Nathalia Bernardes² \\ (Physical Education Professional) \\ Maria Cláudia Irigoyen ${ }^{5}$ \\ (Physician) \\ Katia De Angelis ${ }^{2,6}$ \\ (Physical Education Professional)
}

1. Universidade São Judas Tadeu,

São Paulo, SP, Brazil.

2. Universidade Nove de Julho,

Translational Physiology Laboratory,

São Paulo, SP, Brazil.

3. Universidade do Estado do Pará,

Altamira, PR, Brazil.

4. Universidade Federal do

Maranhão, São Luís, MA, Brazil.

5. Blood Pressure Unit, Instituto

do Coração (InCor), Faculdade de

Medicina da Universidade de São

Paulo, São Paulo, SP, Brazil.

6. Escola Paulista de Medicina,

Department of Physiology.

Universidade Federal de São Paulo

(UNIFESP), São Paulo, SP, Brazil.

\section{Correspondence:}

Katia De Angelis

Escola Paulista de Medicina,

Universidade Federal de São Paulo

(UNIFESP). Rua Botucatu, 862,

Edifício de Ciências Biomédicas, $5^{\circ}$ andar, Vila Clementino, São Paulo, SP, Brasil. 04023-062.

prof.kangelis@yahoo.com.br

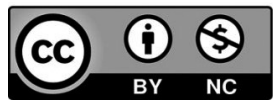

\begin{abstract}
Introduction: Regular physical exercise, or a more active lifestyle, are important to prevent cardiovascular diseases, reducing not only cardiovascular mortality but also promoting a reduction in the risk factors related to these diseases. Objective: To assess the association between physical inactivity and heart rate variability (HRV) in adolescents. Methods: This was a cross-sectional study of the Diagnostic Type with Level of Evidence II according to the Oxford table. One hundred and twenty-nine adolescents were evaluated, aged 15 and 17 years old, divided into four groups: male teenagers who were insufficiently active (IAM $n=28)$ or physically active (FAM $n=29$ ), and female teenagers who were insufficiently active (IAF $n=42$ ) or physically active $($ FAF $n=30)$. The level of physical activity was assessed by the IPAQ. The HRV was evaluated in the time and frequency domains. Results: Reduced pulse interval variance was observed in the insufficiently active male or female groups (5089 $\pm 378 \mathrm{~ms}^{2}$ and $4335 \pm 276 \mathrm{~ms}^{2}$ respectively) compared to the physically active groups $\left(9106 \pm 606 \mathrm{~ms}^{2}\right.$ and $6182 \pm 366 \mathrm{~ms}^{2}$ respectively). Moreover, the insufficiently active groups presented higher cardiac sympathetic/vagal balance values ( $0.81 \pm 0.05$ and $0.80 \pm 0.05$ respectively) compared to the physically active groups ( $0.63 \pm 0.05$ and $0.55 \pm 0.05$ respectively). Conclusion: A physically active lifestyle was associated with better cardiovascular autonomic modulation in adolescents. Level of Evidence Il; Diagnostic Studies Investigating a Diagnostic Test.
\end{abstract}

Keywords: Sedentary lifestyle; Autonomic nervous system; Adolescent health.

\section{RESUMO}

Introdução: A prática regular de exercícios físicos ou o estilo de vida mais ativo são importantes na prevenção de doenças cardiovasculares, reduzindo não somente a mortalidade cardiovascular, mas também favorecendo a redução dos fatores de risco relacionados com essas doenças. Objetivo: Avaliar a associação entre inatividade física e variabilidade da frequência cardíaca (VFC) em adolescentes. Métodos: Este foi um estudo transversal do tipo Diagnóstico com Nivel de Evidência Il segundo a tabela de Oxford. Foram avaliados 129 adolescentes com idades entre 15 e 17 anos, divididos em quatro grupos: adolescentes insuficientemente ativos (IAM, $n=28$ ) ou fisicamente ativos (FAM, $n$ $=29)$ do sexo masculino e adolescentes, insuficientemente ativos (IAF, $n=42)$ ou fisicamente ativos do sexo feminino $(F A F, n=30)$. O nível de atividade física foi avaliado por meio do IPAQ. A VFC foi avaliada no domínio do tempo e da frequência. Resultados: Nos adolescentes do sexo masculino e feminino, foram observados valores menores na variância do intervalo de pulso nos grupos insuficientemente ativos $\left(5.089 \pm 378 \mathrm{~ms}^{2}\right.$ e $4.335 \pm 276 \mathrm{~ms}^{2}$, respectivamente) quando comparados com os grupos fisicamente ativos (9.106 $\pm 606 \mathrm{~ms}^{2} \mathrm{e} 6.182 \pm 366 \mathrm{~ms}^{2}$, respectivamente). Além disso, os grupos insuficientemente ativos apresentaram maiores valores de balanço simpato-vagal cardíaco $(0,81 \pm 0,05$ e 0,80 $\pm 0,05$, respectivamente) comparados aos dos grupos fisicamente ativos $(0,63 \pm 0,05$ e 0,55 $\pm 0,05$, respectivamente). Conclusão: A vida fisicamente ativa foi associada à melhor modulação cardiovascular autonômica em adolescentes. Nível de Evidência ll; Estudos diagnósticos - Investigação de um exame para diagnóstico.

\section{Descritores: Estilo de vida sedentário; Sistema nervoso autônomo; Saúde do adolescente.}

\section{RESUMEN}

Introducción: La práctica regular de ejercicios físicos o el estilo de vida más activo son importantes en la prevención de enfermedades cardiovasculares, reduciendo no sólo la mortalidad cardiovascular, sino también favoreciendo la reducción de los factores de riesgo relacionados con esas enfermedades. Objetivo: Evaluar la asociación entre inactividad física y variabilidad de la frecuencia cardíaca (VFC) en adolescentes. Métodos: Este fue un estudio transversal del tipo Diagnóstico con Nivel de Evidencia Il según la tabla de Oxford. Se evaluaron 129 adolescentes con edades entre 15 y 17 años, divididos en cuatro grupos: adolescentes insuficientemente activos (IAM, $n=28)$ o físicamente activos (FAM, $n=29)$ del sexo masculino y adolescentes insuficientemente activos (IAF, $n=42)$ o físicamente activos del sexo femenino (FAF, $n=30$ ). El nivel de actividad física fue evaluado a través del IPAQ. La VFC fue evaluada en el dominio 
del tiempo y de la frecuencia. Resultados: Los adolescentes del sexo masculino y femenino insuficientemente activos presentaron valores menores en la varianza del intervalo de pulso (5.089 $\pm 378 ; y 4.335 \pm 276 \mathrm{~ms}^{2}$, respectivamente) cuando se compararon con los grupos físicamente activos ( $9.106 \pm 606$ y $6.182 \pm 366 \mathrm{~ms}^{2}$, respectivamente). Además, los grupos insuficientemente activos presentaron mayores valores del balance simpático-vagal cardíaco $(0,81 \pm 0,05$ y $0,80 \pm 0,05$, respectivamente) comparados a los grupos físicamente activos (0,63 $\pm 0,05$ y 0,55 $\pm 0,05$, respectivamente). Conclusión: La vida físicamente activa fue asociada a la mejor modulación cardiovascular autonómica en adolescentes.

\section{Nivel de Evidencia ll; Estudios de diagnósticos - Investigación de un examen para diagnóstico.}

Descriptores: Estilo de vida sedentario; Sistema nervioso autónomo; Salud del adolescente.

\section{INTRODUCTION}

Physical activity levels in children and adolescents have shown a significant reduction, which may be related to the increase in the use of computer games and television. ${ }^{1}$ According to the I Guidelines for the Prevention of Atherosclerosis in Childhood and Adolescence, depending on the criteria used, there is a prevalence of $42 \%$ to $93.5 \%$ of sedentarism in this population ${ }^{2}$ and a $60-70 \%$ risk of developing hypertension, ${ }^{3}$ which does not occur with regular exercise, which is efficient in reducing cardiovascular mortality. ${ }^{4}$

There is evidence that cardiovascular autonomic dysfunction plays an important role in the development and worsening of various diseases. ${ }^{5}$ In this sense, heart rate variability (HRV) analysis has been a non-invasive tool for the evaluation of cardiovascular autonomic modulation, demonstrating that HRV reduction is associated with increased cardiovascular morbidity and mortality. ${ }^{6}$

Due to the cardiovascular benefits, such as reduced resting heart rate, metabolic benefits, inhibition of insulin secretion stimulating lipolysis in adipose tissue 7,8 and improved autonomic control, many investigators suggest physical training as a non-pharmacological conduct in the prevention of various diseases, such as systemic arterial hypertension, heart failure, diabetes and obesity. ${ }^{8,9}$

Despite consensus on the importance of physical activity in the treatment of cardiovascular dysfunctions, few studies have demonstrated the importance of this practice in adolescents. The objective of this study was to evaluate the association between physical inactivity and HRV in adolescents.

\section{METHODS}

This is a cross-sectional Diagnostic with Level of Evidence II type of study according to the Oxford table, approved by the Ethics Committee of Universidade São Judas Tadeu (090/2009) and according to the Declaration of Helsinki, revised in 2008. At first, Informed Consents were sent to the parents of adolescents from a state school in São Paulo, of which 113 were not returned or did not contain the requested data. The study included 129 male and female adolescents aged between 15 and 17, according to the flowchart. (Figure 1)

To assess physical activity levels, the participants filled out a self-reported IPAQ short version. For the purposes of setting up the groups, the adolescents were classified as active, irregularly active (A and B) and sedentary. A statistical analysis using Student's t-test to compare the irregularly active groups found no significant differences for anthropometric, metabolic, hemodynamic and autonomic variables between them. Therefore, these individuals (male or female) were included in the so-called insufficiently active groups. We then distributed the individuals in four groups, (Figure 2), namely: Insufficiently active males (IAM, $n=28)$ or females (IAF, $n=42)$ and physically active males (PAM, $n=29$ ) or females (PAF, $n=30$ ).

Body weight and height were measured barefoot in orthostatic position, feet joined and facing forward, using Filizola digital scales and Sanny stadiometer, respectively. ${ }^{\circledR}$ From these data, body mass index (BMI) was calculated. BMI, age, height and body mass (Kg) percentiles were entered into the software STAT GROWTH CHARTS $^{\text {TM }}$, version 2.04 of the Austin Physician Productivity for iPod. The adolescents who had

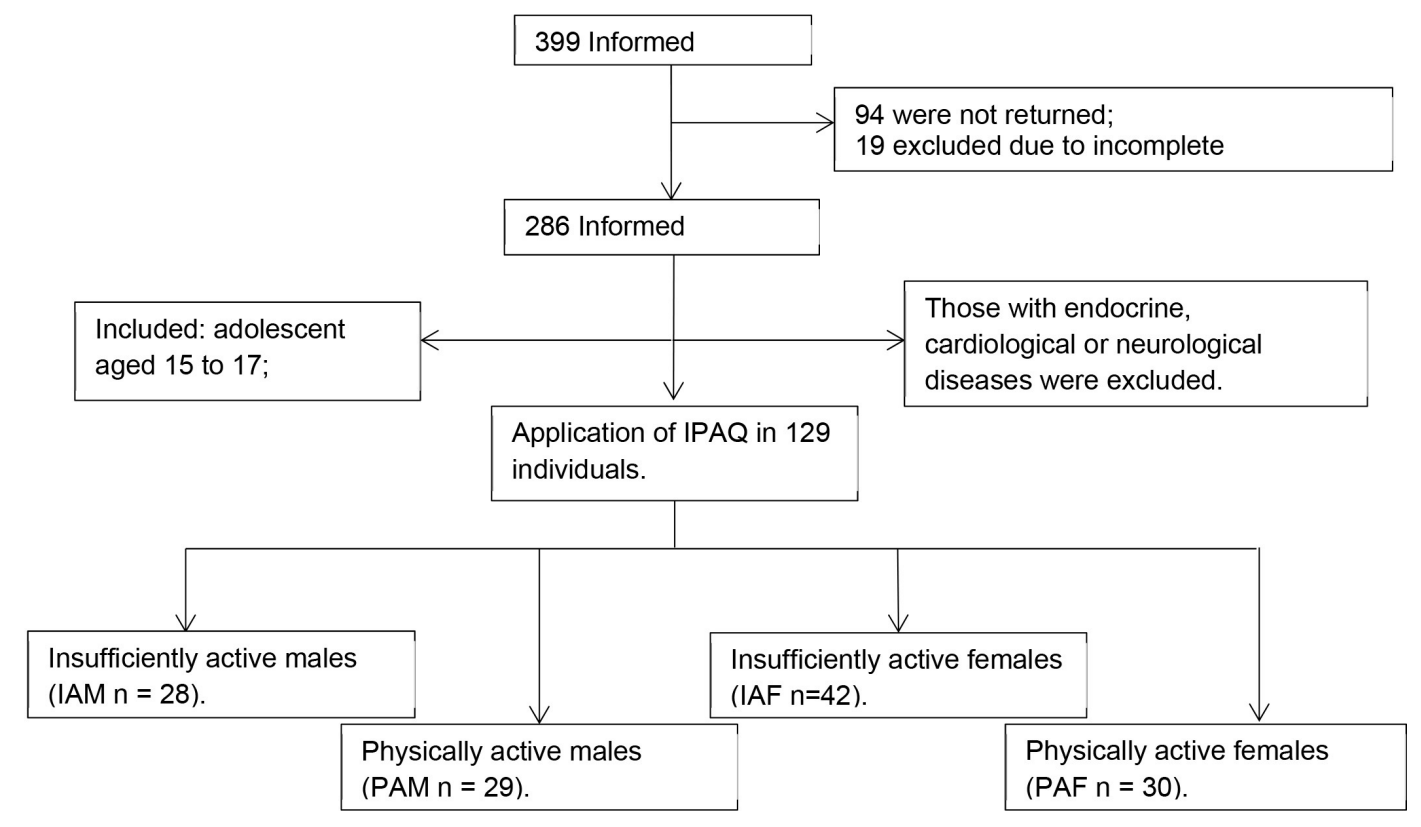

Figure 1. Flowchart. 


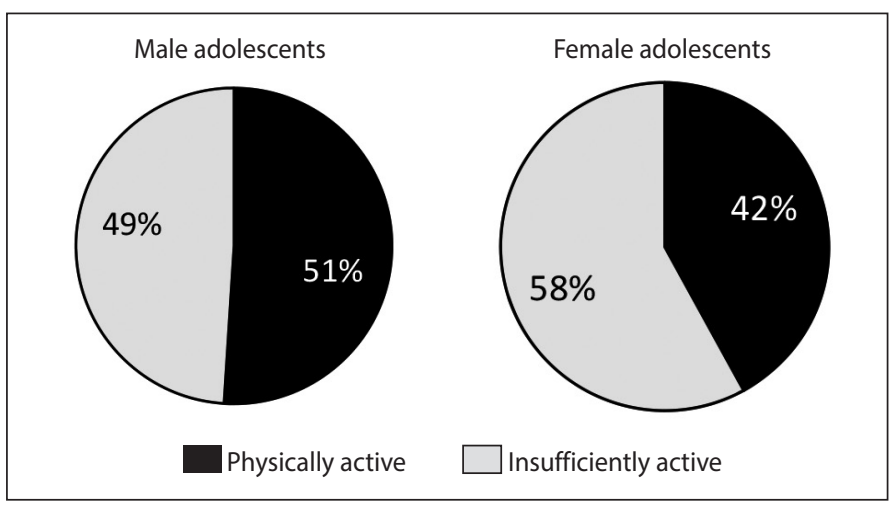

Figure 2. Percentage of male or female adolescents according to the level of physical activity.

equal or lower percentiles $(<5)$ were classified as low weight; those with equal or lower percentiles ( $>5$ and $<85$ ) were classified as healthy weight; percentiles lower than 95 were classified as overweight ( $>85$ and $<95$ ); and percentiles ( $\geq 95)$ were classified as obese.

Measurements of waist circumference (WC) were taken with the adolescents in an orthostatic position, with relaxed abdomen, on the narrower portion of the trunk, using a flexible Sanny tape measure placed on the horizontal plane. ${ }^{\circledR}$

Measurements of blood pressure (BP) were taken with the adolescents sitting at rest, at three moments: two measurements at the beginning of collection and one measurement immediately after the evaluation of autonomic modulation, whereby the first measurement was disregarded and the mean of the last two measures was taken. The method used was auscultatory with Missouri ${ }^{\circledR}$ aneroid sphygmomanometer and Littmann ${ }^{\circledR}$ stethoscope in the right arm. All measurements were taken by the same evaluator and the BP percentiles were derived from the analysis of the data entered into the STAT GROWTH CHARTS ${ }^{\text {TM }}$, complying with and classified according to the VII Brazilian Guidelines on Hypertension (2016).

The RR interval was recorded with the adolescents sitting and instructed to perform minimal voluntary movements for three minutes, using a S810 Polar frequency meter. On the frequency meter, the transmitting belt detects the beat-to-beat electrocardiographic signal and transmits it through an electromagnetic wave to the Polar wrist receiver where this information is scanned, displayed and filed. The system detects ventricular depolarization corresponding to the electrocardiogram $\mathrm{R}$ wave with a $500 \mathrm{HZ}$ sampling and a time resolution of one $\mathrm{ms}^{10}$ previously validated against standard Holter electrocardiography. ${ }^{11}$

The log files were transferred to the Polar Precision Performance Software through the Infrared Interface, or IrDA, which allows bidirectional data exchange. RR series variances were evaluated for time domain and frequency domain. ${ }^{12}$ After acquisition and storage of the data in the computer, the RR intervals (IP) from the frequency meter were converted and stored in Excel files to select the sections to be analyzed by visual inspection in order to identify and/or correct any incorrect markings. Then, the time series of each signal to be studied (tachogram) was generated. The data were analyzed and tabulated using the MATLAB program in the Fast Fourier Transform (FFT) format. After this mathematical remodeling, the absolute power was derived in the relevant pre-determined frequency bands: low frequency (LF: 0.04-0.15 Hz, indicative of cardiac sympathetic modulation) and high frequency (HF: $0.15-0.4 \mathrm{~Hz}$, indicative of cardiac parasympathetic modulation). Data are expressed in absolute values and standard units. The LF/HF ratio represents the sympathovagal balance. Detection of RR intervals from the frequency meter followed the same criteria described above for setting up the time series of the frequency domain variability. For this study, mean standard deviation (SD) and total variance (PIVAR) were used as an index in the time domain. ${ }^{13}$
Metabolic measurements were performed with adolescents previously instructed to fast for 12 hours. The collection took place in an environment of controlled access, in the school building, using individual sterilized disposable Roche Accu-Check Safe T-ProUno lancets. Asepsis of the index finger was done with MEDLINE ${ }^{\circledR} 70 \%$ alcohol SWAB. Roche Accutrend Plus ${ }^{\circledR}$ portable reflectance photometry monitors were used for specific measurements of blood glucose, cholesterol and triglycerides.

Body composition evaluation was performed with the individual lying in dorsal decubitus in an environment reserved by the method of electrical bioimpedance with Biodynamics BIA ${ }^{\circledR} 450$ equipment. To perform this procedure, the adolescents were instructed to fast for 12 hours, abstaining from caffeine, alcohol and exercise for at least 24 hours, not ingesting water for four hours and emptying their bladder 30 minutes before the procedure. Immediately before the placement of electrodes, the contact areas were cleaned with $70 \%$ alcohol and plain cotton. One emitter electrode was placed close to the metacarpal phalangeal joint of the dorsal surface of the right hand and another one distally from the transverse arch of the upper surface of the right foot. One detector electrode was placed between the distal prominences of the radius and ulna of the right wrist and another one between the medial and lateral malleoli of the right ankle, following the manufacturer's recommendations.

\section{Statistical analysis}

The results are presented by sex, as mean \pm standard error of the mean for numerical variables and as frequency and percentage for categorical variables. To analyze the categorical variables, chi-square test was used using the software SPSS version 18.0. The variances of the other anthropometric, metabolic, hemodynamic and autonomic variables of the groups were compared by two-way ANOVA, followed by Student Newman Keuls post hoc using the software STATISTICA version 9. The significance level adopted in this study was $p<0.05$. The power of the sample was calculated subsequently considering the group variances for the following variables: sympatho-vagal balance and pulse interval variance. $A \beta$ of 0.99 was derived for $L F / H F$ and a $\beta$ of 1.00 for PI VAR.

\section{RESULTS}

Regarding the regular practice of physical activity, we found that $54 \%$ of the total sample of adolescents were considered insufficiently active according to the IPAQ evaluation criteria. Among male adolescents, $49 \%$ were classified as insufficiently active, and $58 \%$ of females were classified as such. (Figure 2)

Regarding the participation in physical education classes at school, $27.5 \%$ of male adolescents and $51.4 \%$ of female adolescents reported not attending the classes regularly.

Among male adolescents, we found no differences regarding age, BMI and systolic and diastolic blood pressure considering the level of physical activity (Table 1). In heart rate variability evaluations, we found lower mean SD and PI VAR values in the IAM group (74 \pm 4 ms and $5089 \pm 378 \mathrm{~ms}^{2}$, respectively) compared to the PAM group (90 $\pm 4 \mathrm{~ms}$ and $9106 \pm 606 \mathrm{~ms}^{2}$, respectively) (Figure 3). Also, we found higher low frequency (LF) band and sympathetic/vagal balance (LF/HF) values in the IAM group ( $42 \pm 1.5 \%$ and $0.81 \pm 0.05$, respectively) compared to the PAM group ( $35 \pm 1.7 \%$ and $0.63 \pm 0.05$, respectively) (Figure 3 ). In the high frequency (HF) band, the IMA group presented lower values (58 $\pm 1.5 \%)$ compared to the PAM group (64 $\pm 1.7 \%)$.

In female adolescents, we did not find any difference of age, BMI and systolic and diastolic BP. (Table 1) In the heart rate variability evaluations, we found lower SD and PIVAR values in the IAF group (61 $\pm 3 \mathrm{~ms}$ and $4335 \pm 276 \mathrm{~ms}^{2}$, respectively) compared to the PAF group (73 $\pm 4 \mathrm{~ms}$ and $6182 \mathrm{~ms} \pm 366 \mathrm{~ms}^{2}$, respectively). (Figure 3 ) In the LF band and in the IP LF/HF, the IAF group presented higher values ( $40 \pm 1.4 \%$ and 0.80 
Table 1. Characterization of groups of insufficiently active male adolescents (IAM) or physically active male adolescents (PAM) and insufficiently active female adolescents (IAF) and physically active female adolescents (PAF).

\begin{tabular}{c|c|c|c|c}
\hline Groups & IAM & PAM & IAF & PAF \\
\hline Age (years) & $16 \pm 0.1$ & $16 \pm 0.2$ & $16 \pm 0.2$ & $16 \pm 0.2$ \\
\hline BMl $\left(\mathrm{kg} / \mathrm{m}^{2}\right)$ & $22 \pm 1.0$ & $21 \pm 0.6$ & $22 \pm 0.5$ & $23 \pm 0.7$ \\
\hline $\mathrm{SBP}(\mathrm{mmHg})$ & $119 \pm 2.6$ & $116 \pm 2.0$ & $109 \pm 1.2$ & $108 \pm 1.3$ \\
\hline $\mathrm{DBP}(\mathrm{mmHg})$ & $72 \pm 1.8$ & $66 \pm 1.0$ & $66 \pm 1.1$ & $67 \pm 1.2$ \\
\hline
\end{tabular}

Values representing mean \pm standard error of the mean. Body mass index — BMI, systolic blood pressure - SBP diastolic blood pressure - DBP, standard deviation - SD

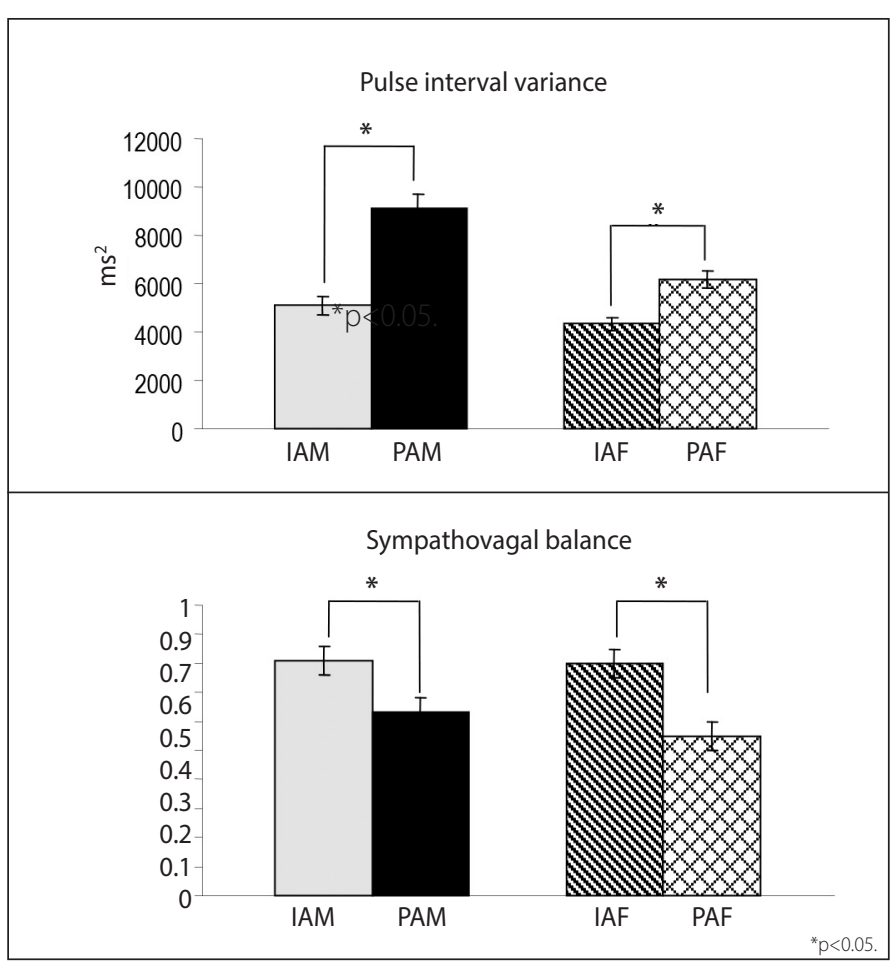

Figure 3. Pulse interval variance and cardiac sympathovagal balance of the groups of insufficiently active male adolescents (IAM) or physically active male adolescents (PAM) and insufficiently active female adolescents (IAF) female adolescents and physically active female adolescents (PAF).

\pm 0.05 , respectively) compared to the PAF group ( $32 \pm 1.6 \%$ and $0.55 \pm$ 0.05 , respectively). (Figure 3 ) In the HA band, the IAF group presented lower values $(59 \pm 1.4 \%)$ compared to the PAF group ( $67 \pm 1.7 \%)$.

\section{DISCUSSION}

Considering that sedentarism may be one of the main risk factors for cardiovascular diseases and that few studies investigated the prevalence and its implications in adolescents of both sexes, this study evaluated the association between physical activity and HRV in young people aged 14 to 17 .

We observed that female adolescents have a lower participation in physical education classes at school compared to male adolescents. In this sense, a longitudinal study conducted with female adolescents found that girls after the puberty period presented a 50\% decline in the level of physical activity. The same was not observed in male adolescents. ${ }^{14}$ Other studies found that the prevalence of physical inactivity in female adolescents was higher (58.4\%) than in male adolescents (48.3\%). ${ }^{14,15,16}$ Moreover, investigations using data from the questionnaire proposed by the National Children and Youth Fitness Study I show that male adolescents are 15 to $25 \%$ more active than female adolescents. ${ }^{17}$

Although there are insufficient epidemiological data describing the prevalence of physical activity habits among Brazilian adolescents, according to the I Guidelines for Prevention of Atherosclerosis in Childhood and Adolescence, which includes studies conducted with different criteria, there is a prevalence of $42 \%$ to $93.5 \%$ of sedentarism in childhood and adolescence. ${ }^{2}$
It is worth noting that other studies that associated low levels of physical activity with important cardiovascular risk factors such as excess fat mass, hyperglycemia, hyperinsulinemia, hypertension and dyslipidemia, demonstrated strong associations of these diseases with decreased regular exercising. ${ }^{18,19}$ In addition to that, different studies with adults suggest that regularly practicing some kind of physical activity may be beneficial in the treatment of various diseases and effectively helps preventing the onset of cardiovascular diseases. ${ }^{9}$

In addition to physical inactivity, autonomic dysfunction can be considered an independent factor and a predictor of mortality for different populations, ${ }^{20}$ since the modulation of autonomic sympathetic and parasympathetic activity on the heart may be associated with multiple clinical and functional conditions that may be determinants in cardiovascular conditions. ${ }^{21,22}$ Particularly, increased sympathetic activity is considered a major contributor to increased index of chronic diseases. ${ }^{23}$

Because it is an accessible tool and mainly a non-invasive method, HRV analysis has been increasingly used and very reliable and reproducible data has been generated. ${ }^{24}$

A study in adults with autonomic control dysfunctions demonstrated a strong relationship between HRV dysfunction and lifestyle, since adults with sedentary habits demonstrate lower HRV values. ${ }^{25}$ In this study, adolescents classified as insufficiently active showed lower SD and PIVAR values compared with groups of physically active individuals. Corroborating with our results, a study comparing male adolescent athletes with male sedentary adolescents also found reduced PIVAR in the sedentary group. ${ }^{26}$ Likewise, lower SD and PI VAR values were also observed in adolescents with lower levels of physical fitness and with excess weight. ${ }^{27}$ Also, in our study, we observed significantly higher LF and LF/HF values, representative of cardiac sympathetic modulation, in the groups of insufficiently active adolescents compared with physically active groups. In fact, in a study comparing athletic and sedentary male adolescents, it was found that the group of athletes presented reduced cardiac sympathetic modulation represented by decreased LF and LF/HF. ${ }^{26}$

It is worth noting that most of the studies evaluating HRV and its relationship with a sedentary lifestyle were performed in adult males or in mixed samples. In this sense, in this study, we found that adolescents with lower levels of physical activity, regardless of sex, present reduced cardiac parasympathetic modulation. Our results corroborate data from Alom et al., who found increased vagal cardiac modulation in adolescent athletes compared with sedentary adolescents. ${ }^{26}$ Furthermore, literature data show that sedentary behavior in women induces impaired autonomic cardiac modulation at rest and in response to physiological stress. ${ }^{28}$ Interestingly, increased sympathetic modulation concomitant with decreased cardiac parasympathetic modulation also occurs in obese adolescents compared with eutrophic adolescents. ${ }^{29}$ In this sense, it is worth mentioning that obesity in adolescence is significantly associated with a sedentary lifestyle, ${ }^{30}$ which may lead to increased cardiovascular risk in adulthood.

\section{CONCLUSION}

Thus, we can conclude that regardless of sex, a physically active life was associated with better cardiovascular autonomic modulation in adolescents. In this context, we suggest that physical activity should be integrated into the daily routine of adolescents of both sexes.

\section{ACKNOWLEDGEMENTS}

Sources of funding: CNPq 4673001/2014-3; CNPq: 476373/2012-3; CNPq HASCA: 467300/2014-3.

All authors declare no potential conflict of interest related to this article 
AUTHORS' CONTRIBUTIONS: Each author made significant individual contributions to this manuscript. RDN (0000-0003-2438-6596)* and KDA (0000-0002-3640-9049)*: conception and design of the research, obtaining data, analysis and interpretation of the data, statistical analysis, obtaining financing, writing and critical review of the intellectual content; AV (0000-0003-3866-5000)* analysis and interpretation of the data, statistical analysis, writing the manuscript and critical review of the intellectual content; MS (0000-0002-3874-6508)* DSD (0000-0003-4152-0849)*, JOBM (0000-0001-6384-4452)* and NB (0000-0001-9555-4134)*: obtaining data, analysis and interpretation of the data, statistical analysis; JRZJ (00000003-2045-8556)*: writing the manuscript and critical review of the intellectual content; MCI (0000-0003-2097-3662)*: conception and design of the research, critical review of the manuscript and intellectual content. All authors approved the final version of the manuscript. *ORCID (Open Researcher and Contributor ID).

\section{REFERENCES}

1. Lopes VP, Vasques CM, Pereira MB, Maia JA, Malina RM. Physical activity patterns during school recess: a study in children 6 to 10 years old. Int Electron J Health Educ. [Internet]. 2006 [acesso em 2016 fev 13];9:192-201. Disponível em: http://eric.ed.gov/?id=EJ794139

2. Back Giuliano Ide C, Caramelli B, Pellanda L, Duncan B, Mattos S, Fonseca FH; Sociedade Brasileira de Cardiologia. I Diretriz de prevenção da aterosclerose na infância e na adolescência. Arq Bras Cardiol. 2005;85(Suppl 6):4-36

3. Haapanen N, Milunnalo S, Vuori I, Oja P, Pasanen M. Association of leisure time physical activity with the risk of coronary heart disease, hypertension and diabetes in middle-aged men and women. Int Epidemiol. [Internet]. 1997 [acesso em 2016 fev 13];26(4):739-47. Disponivel em: http://ije.oxfordjournals. org/content/26/4/739.short

4. Brum PC, Rondon MU, Silva GJ da, Krieger EM. Hipertensão arterial e exercício físico aeróbico. In: Negrão CE Barreto AC. Cardiologia do exercício: do atleta ao cardiopata. Barueri - SP: Manole; 2005.167-78.

5. De Angelis K, Santos MS, Irigoyen MC. Sistema nervoso autônomo e doença cardiovascular. Rev Soc Cardiol Rio Gd Sul. [Internet]. 2004 [acesso 2015 mai 15];13(3):1-7. Disponível em: http://sociedades. cardiol.br/sbc-rs/revista/2004/03/artigo02.pdf

6. Task Force of the European Society of Cardiology, North American Society of Pacing and Electrophysiology. Heart rate variability. Standards of measurement, physiological interpretation, and clinical use. Eur Heart J. [Internet]. 1996 [acesso em 2016 fev 13];17(3):354-81. Disponível em: http://ci.nii.ac.jp/naid/10010551356/

7. Ivy JL. Role of exercise training in the prevention and treatment of insulin resistance and non-insulindependent diabetes mellitus. Sports Med. [Internet]. 1997 [acesso em 2016 fev 13];24(5):321-36. Disponível em: http://link.springer.com/article/10.2165/00007256-199724050-00004

8. Gordon NF, Scott CB, Levine BD. Comparison of single versus multiple lifestyle interventions: are the antihypertensive effects of exercise training and diet-induced weight loss additive? Am J Cardiol. [Internet]. 1997 [acesso em 2016 fev 13];79(6):763-7. Disponível em: http://www.sciencedirect.com/ science/article/pii/S0002914996008648

9. De Angelis K, Ogawa T, Sanches IC, Rigatto KV, Krieger EM, Irigoyen MC. Impairment on cardiac output and blood flow adjustments to exercise in L-NAME-induced hypertensive rats. J Cardiovasc Pharmacol. [Internet]. 2006 [acesso em 2016 fev 13];47(3):371-6. Disponível em: http://journals.lww.com/ cardiovascularpharm/Abstract/2006/03000/Impairment_on_Cardiac_Output_and_Blood_Flow.6.aspx

10. Ruha A, Sallinen S, Nissilä S. A real-time microprocessor QRS detector system with a 1-ms timing accuracy for the measurement of ambulatory HRV. IEEE Trans Biomed Eng. [Internet]. 1997 [acesso em 2016 fev 13];44(3):159-67. Disponível em: http://ieeexplore.ieee.org/xpls/abs_all.jsp?arnumber=554762

11. Loimaala A, Sievanen H, Laukkanen R, Parkka J,Vuori I, Huikuri H. Accuracy of a novel real-time microprocessor QRS detector for heart rate variability assessment. Clin Physiol. [Internet]. 1999 [acesso em $2016 \mathrm{fev}$ 13];19(1):84-8. Disponível em: http://onlinelibrary.wiley.com/doi/10.1046/j.1365-2281.1999.00152.x/full

12. Malliani A, Pagani M, Lombardi F, Cerutti S. Cardiovascular neural regulation explored in the frequency domain. Circulation. [Internet]. 1991 [acesso em 2016 fev 13];84(2):482-492. Disponível em: http://circ ahajournals.org/content/84/2/482.short

13. Ishise $\mathrm{H}$, Asanoi $\mathrm{H}$, Ishizaka $\mathrm{S}$, Joho $\mathrm{S}$, Kameyama $\mathrm{T}$, Umeno $\mathrm{K}$, et al. Time course of sympathovagal imbalance and left ventricular dysfunction in conscious dogs with heart failure. J Appl Physiol (1985). [Internet]. 1998 [acesso em 2016 fev 13];84(4):1234-41. Disponível em: http://jap.physiology.org/ content/84/4/1234.abstract

14. Ceschini FL, Andrade DR, Oliveira LC, Araújo Júnior JF, Matsudo VK. Prevalence of physical inactivity and associated factors among high school students from state's public schools. J Pediatr (Rio J). [Internet]. 2009 [acesso em 2016 fev 13];85(4):301-6. Disponível em: http://www.scielo.br/scielo. php?pid=\$0021-75572009000400006\&script=sci_arttext

15. Meredith CN, Dwyer JT. Nutrition and exercise: effects on adolescent health. Annu Rev Public Health. [Internet]. 1991 [acesso em 2016 fev 13];12:309-33. Disponível em: http://www.annualreviews.org/doi/ pdf/10.1146/annurev.pu.12.050191.001521

16. Adami F, Frainer DE, Santos JS, Fernandes TC, De-Oliveira FR. Insatisfação corporal e atividade física em adolescentes da região continental de Florianópolis. Psicol Teor Pesquisa. [Internet]. 2008 [acesso em 2016 fev 13];24(2):143-9. Disponível em: http://www.ufjf.br/labesc/files/2011/04/ Insatisfa\%C3\%A7\%C3\%A30-1.pdf

17. Sallis JF, McKenzie TL, Alcaraz JE. Habitual physical activity and health-related physical fitness in fourthgrade children. Am J Dis Child. [Internet]. 1993 [acesso em 2016 fev 13];147(8):890-6. Disponível em: http://archpedi.jamanetwork.com/article.aspx?articleid=516827

18. Mokdad AH, Mensah GA, Posner SF, Reed E, Simoes EJ, Engelgau MM, et al. When chronic conditions become acute: prevention and control of chronic diseases and adverse health outcomes during natural disasters. Prev Chronic Dis. [Internet]. 2005 [acesso em 2016 fev 13];2(Spec no):A04. Disponível em: http:// www.cdc.gov/PCD/issues/2005/nov/pdf/05_0201.pdf

19. Eckel RH, Daniels SR, Jacobs AK, Robertson RM. America's children: a critical time for prevention. Circulation. [Internet]. 2005 [acesso em 2016 fev 13];111(15):1866-8. Disponível em: http://circ.ahajournals.org/ content/111/15/1866.short

20. Kristal-Boneh E, Raifel M, Froom P, Ribak J. Heart rate variability in health and disease. Scand J Work Environ Health. [Internet]. 1995 [acesso em 2016 fev 13];21(2)85-95. Disponivel em: http://www.jstor. org/stable/40966336

21. dos Reis AF dos, Bastos BG, Mesquita ET, Romêo Filho LJ, Nóbrega AC. da. Disfunção parassimpática, variabilidade da freqüência cardíaca e estimulação colinérgica após infarto agudo do miocárdico. Arq Bras Cardiol. [Internet]. 1998 [acesso em 2016 fev 13];70(3):193-9. Disponível em: http://www.scielo.br/ scielo.php?pid=S0066-782X1998000300011\&script=sci_arttext\&tlng=pt

22. Junqueira Jr LF. Disfunção Autonômica Cardíaca. In: Porto CC. Doenças do Coração -Tratamento e Reabilitação. Rio de Janeiro: Guanabara-Koogan; 1998. p. 306-11.

23. Wakabayashi S, Aso Y. Adiponectin concentrations in sera from patients with type 2 diabetes are negatively associated with sympathovagal balance as evaluated by power spectral analysis of heart rate variation. Diabetes Care. [Internet]. 2004 [acesso em 2016 fev 13];27(10):2392-7. Disponível em: https:// care.diabetesjournals.org/content/27/10/2392.full

24. Lucini D, Guzzetti S, Casiraghi S, Pagani M. Correlation between baroreflex gain and 24-h indices of heart rate variability. J Hypertens. [Internet]. 2002 [acesso em 2016 fev 13];20(8):1625-31. Disponível em: http://journals.lww.com/jhypertension/Abstract/2002/08000/Correlation_between_baroreflex_gain_and_24_h.26.aspx

25. Tuomainen P, Hartikainen J, Vanninen E, Peuhkurinen K. Warm-up phenomenon and cardiac autonomic control in patients with coronary artery disease. Life Sci. [Internet]. 2005 [acesso em 2016 fev 13];76(19):2147-58. Disponível em: http://www.sciencedirect.com/science/article/pii/50024320505000184

26. Alom M, Begum N, Ferdousi S, Begum S, AliT. Power spectral analysis of heart rate variability in adolescent male athletes. J Bangladesh Soc Physiol. [Internet]. 2009 [acesso em 2016 fev 13];4(2):26-33. Disponível em: http://www.banglajol.info/index.php/JBSP/article/viewArticle/4169

27. Schmid K, Schönlebe J, Drexler H, Mueck-Weymann M. Associations between being overweight, variability in heart rate, and well-being in the young men. Cardiol Young. [Internet]. 2010 [acesso em 2016 fev 13];20(1):54-9. Disponível em: http://journals.cambridge.org/abstract_S1047951109992009

28. Zaffalon Júnior JR, Viana AO, de Melo GEL, De Angelis K. The impact of sedentarism on heart rate variability (HRV) at rest and in response to mental stress in young women. Physiol Rep. [Internet] 2018 [acesso em 2019 fev 20];6(18):e13873. Disponível em: https://www.ncbi.nlm.nih.gov/pmc/ articles/PMC6148327/

29. Vanderlei LC, Pastre CM, Freitas Jr IF, Godoy MF. Geometric indexes of heart rate variability in obese and eutrophic children. Arq Bras Cardiol. [Internet]. 2010 [acesso em 2016 fev 13];95(1):35-40. Disponível em: http://www.scielo.br/scielo.php?pid=S0066-782X2010001100006\&script=sci_arttext\&tIng=es

30. Cavalcanti CB, Barros MV, Menêses AL, Santos CM, Azevedo AM, Guimarães FJ. Abdominal obesity in adolescents: prevalence and association with physical activity and eating habits. Arq Bras Cardiol. [Internet]. 2010 [acesso em 2016 fev 13];94(3):371-7. Disponível em: http://www.scielo.br/scielo. php?pid=S0066-782X2010000300015\&script=sci_arttext 